\title{
Neutralizing Antibodies in Cats Infected with Feline Immunodeficiency Virus
}

\author{
FRANCO TOZZINI, ${ }^{1}$ DONATELLA MATTEUCCI, ${ }^{2}$ PATRIZIA BANDECCHI, ${ }^{1}$ FULVIA BALDINOTTI, ${ }^{2}$ \\ KEES SIEBELINK, ${ }^{3}$ ALBERT OSTERHAUS, ${ }^{3}$ AND MAURO BENDINELLI ${ }^{2 *}$ \\ Department of Animal Pathology ${ }^{1}$ and Department of Biomedicine, ${ }^{2}$ University of Pisa, I-56127 Pisa, \\ Italy, and Laboratory of Immunobiology, National Institute of Public Health and \\ Environmental Protection, 3720 BA Bilthoven, The Netherlands ${ }^{3}$
}

Received 31 August 1992/Accepted 23 February 1993

\begin{abstract}
Sera from cats experimentally infected with five isolates of feline immunodeficiency virus (FIV) from various geographical regions and from FIV enzyme-linked immunosorbent assay-seropositive field cats from four European countries neutralized the Petaluma strain of FIV (FIV-P), originally isolated in California, at high titers. In addition, FIV-P and a European isolate proved equally susceptible to neutralization by all sera tested. Coupled with observations by Fevereiro et al. (M. Fevereiro, C. Roneker, A. Laufs, L. Tavares, and F. de Noronha, J. Gen. Virol. 72:617-622, 1991), these findings indicate that most if not all FIV strains circulating in Europe and the United States share important neutralization-inducing epitopes.
\end{abstract}

Feline immunodeficiency virus (FIV), a widespread cause of disease in domestic cats $(2,9,24)$, shares many properties with human immunodeficiency virus (HIV) and is therefore considered a suitable model for studying aspects of AIDS pathogenesis and treatment which cannot be easily addressed with humans $(15,19)$. Nonetheless, little is known about the ability of FIV to induce neutralizing antibodies (NA). Using a procedure based on infectivity inhibition, Fevereiro et al. (5) found an antibody that neutralizes the prototype Petaluma strain of FIV (FIV-P), originally isolated in California (16), in a limited number of domestic cats from the United States as well as in cats experimentally infected with FIV-P. In the present study, using a recently developed syncytium formation inhibition assay, we showed that FIV strains which circulate in the United States and in Europe are extensively cross-neutralized.

The neutralization assay used has been described elsewhere (22). Briefly, 0.1-ml volumes of twofold dilutions (from $1: 8$ to $1: 16,096$ ) of sera heated at $56^{\circ} \mathrm{C}$ for $30 \mathrm{~min}$ were mixed with $0.1 \mathrm{ml}$ of FIV diluted to contain 1,000 syncytiumforming units $/ \mathrm{ml}$, incubated at room temperature for $1 \mathrm{~h}$, and then inoculated into $0.5 \mathrm{ml}$ of medium in duplicate wells of 24-well plates which were seeded with $10^{4}$ Crandell feline kidney (CrFK-MESNA) cells adapted to grow in a medium containing a low concentration of fetal bovine serum. Each plate included control immune and negative sera. Six days later, the plates were stained with $0.2 \%$ crystal violet in $30 \%$ methanol and examined microscopically. Only syncytia containing seven or more nuclei were counted. The neutralizing titer was expressed as the reciprocal of the highest dilution of serum which prevented the formation of syncytia. Unless otherwise stated, FIV-P was used in the neutralization assay. In some experiments, the Dutch isolate Amsterdam-6 (FIV-A6), which was obtained from a free-roaming cat in the Netherlands and adapted to replication in CrFK-MESNA cells, was also used. Both FIV-P and FIV-A6 consistently produce syncytia on freshly infected CrFK-MESNA cells. The viral stocks used ranged in titer between $4 \times 10^{3}$ and 5 $\times 10^{4}$ syncytium-forming units $/ 0.1 \mathrm{ml}$.

\footnotetext{
${ }^{*}$ Corresponding author.
}

We first examined the sera of specific-pathogen-free (SPF) cats infected with various FIV isolates. Viruses used for infection included FIV-P, two Italian isolates (Pisa-M1 and Pisa-M2 [FIV-M2]), one British isolate (Glasgow-8), one Dutch isolate (Amsterdam-19), and the viral progeny of an infectious molecular clone $(19 \mathrm{k} 1)$ of the last virus $(20)$. The genetic relatedness of these isolates was the subject of a recent report (18). All of the sera of infected cats neutralized FIV with titers ranging from 512 to 8,192 , whereas preinfection sera diluted 1:8 did not. The presence of NA correlated with reactivity in an enzyme-linked immunosorbent assay (ELISA) for FIV antibody (CITE Combo FIV-FeLV; Agritech Systems, Portland, Maine) (data not shown). Figure 1 shows the kinetics of NA production in SPF cats inoculated with FIV-M2. Low levels of NA were already detectable in some cats at day 5 postinfection (Fig. 1, insert), but these antibodies were most likely acquired passively with the plasma used to infect the animals, as the titers declined steadily in the following days. Actively produced NA became clearly evident at 5 to 6 weeks of infection (approximately at the time of seroconversion, as detected by other methods [reference 13 and data not shown]), reached a plateau 3 to 4 months later, and then remained stable for the subsequent period of observation. As shown by periodic isolation of virus from the peripheral blood mononuclear cells by a standard procedure (2), all cats in this group developed a persistent FIV infection.

We then examined sera obtained from naturally infected domestic cats from different European countries. The donors were of many breeds and ages and of both sexes and had different living conditions. Infection was determined serologically by ELISA and in most Italian cats was confirmed by virus isolation. The sera of 43 out of 45 infected cats neutralized FIV at titers ranging from 32 to 4,096 (the other two serum samples, diluted $1: 8$, reduced syncytium formation by over $70 \%$ ). In contrast, the sera of 17 out of 19 noninfected cats were not reactive at a 1:8 dilution. Only two serum samples from culture-negative, ELISA-seronegative cats showed titers of 8 and 16, respectively. In the infected animals, NA titers appeared unrelated to the country of origin (Table 1) or to the clinical status of the cats (data not shown). 


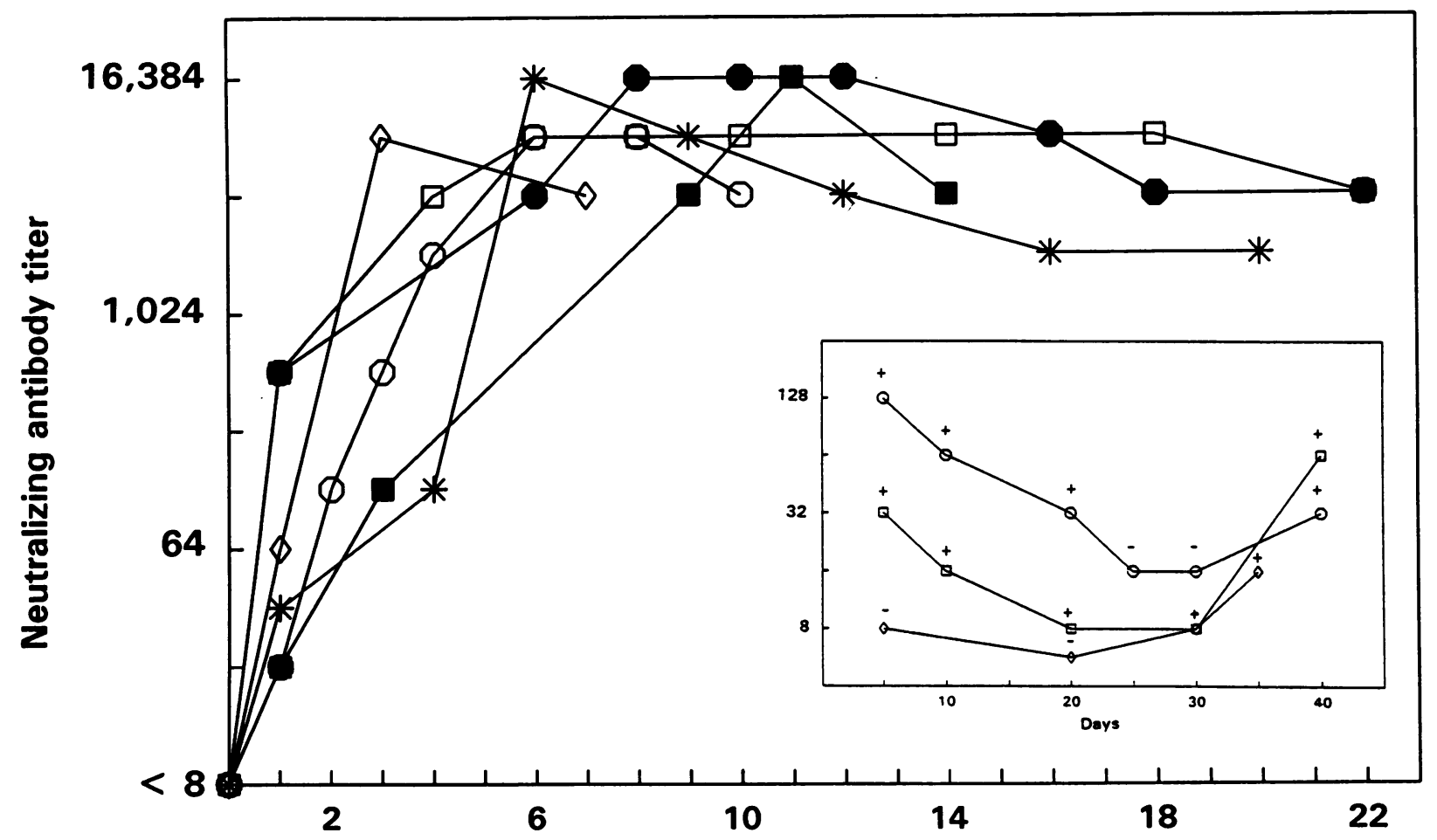

\section{Months post infection}

FIG. 1. NA production in six SPF cats inoculated intravenously with FIV-M2 at an age of 4 to 5 months. This virus is propagated in vivo by monthly passages in SPF cats and at the dose used ( $2 \mathrm{ml}$ of freshly collected blood) leads to a positive FIV ELISA in 4 to 6 weeks and to a reduction in the number of circulating CD4 ${ }^{+}$lymphocytes by almost two-thirds in 1 year (10). During the period of observation, one cat showed progressive emaciation and was killed. The insert shows in more detail the NA titers detected during the first 40 days of infection (+ and - indicate reactivity and nonreactivity, respectively, in the ELISA).

TABLE 1. FIV NA in sera of FIV ELISA-negative and -positive field cats from different European countries

\begin{tabular}{|c|c|c|c|c|}
\hline \multirow[b]{2}{*}{$\begin{array}{l}\text { ELISA result and } \\
\text { country of origin }\end{array}$} & \multirow[b]{2}{*}{$\begin{array}{l}\text { No. of serum } \\
\text { samples } \\
\text { examined }\end{array}$} & \multirow[b]{2}{*}{$\begin{array}{c}\text { No. of serum } \\
\text { samples with } \\
\text { NA }\end{array}$} & \multicolumn{2}{|c|}{ NA titer } \\
\hline & & & Mean $^{b}$ & $\begin{array}{c}95 \% \\
\text { confidence } \\
\text { limits }\end{array}$ \\
\hline Seronegative, Italy & 19 & 2 & 10 & \\
\hline $\begin{array}{l}\text { Seropositive } \\
\text { Italy } \\
\text { The Netherlands } \\
\text { United Kingdom } \\
\text { Switzerland } \\
\text { Sw }\end{array}$ & $\begin{array}{r}21 \\
6 \\
14 \\
4\end{array}$ & $\begin{array}{c}21 \\
6 \\
12^{d} \\
4\end{array}$ & $\begin{array}{r}495 \\
287 \\
1,124 \\
512\end{array}$ & $\begin{array}{r}213-1,150 \\
70-1,179 \\
53-2,488\end{array}$ \\
\hline
\end{tabular}

a All but two FIV-seronegative cats examined were clinically healthy. In contrast, many infected animals presented clinical manifestations (gingivitis, diarrhea, dermatitis, upper respiratory tract infections, anorexia, emaciation, pyrexia, anemia, lymphopenia, lymphadenopathy, or neurological signs) compatible with FIV infection.

${ }^{b}$ Geometric mean of titers $\geq 8$. The means of the infected groups are not significantly different.

c Sera provided by Oswald Jarrett, University of Glasgow.

$d$ At the lowest dilution tested (1:8), the two serum samples that were scored as NA negative reduced FIV-induced syncytium formation by over $70 \%$.

e Sera provided by Hans Lutz, University of Zurich.
The previous data demonstrated the existence of a high degree of serological cross-reactivity among FIV strains which circulate in Europe and the United States. To further investigate this aspect of FIV, we simultaneously titrated against FIV-P and FIV-A6 a panel of 15 serum samples known to contain NA. The sera neutralized the two isolates with similar efficiencies, irrespective of the virus used to immunize the animals or the geographical origin of the donors (data not shown).

The results presented above are at variance with those reported for HIV, whose sensitivity to antibody-mediated neutralization is generally markedly influenced by the source of sera (12). As prior studies with HIV had indicated that, in vitro, certain antibodies may cause a dissociation between syncytium formation and virus replication and/or produce neutralization even if added to cultures after virus is bound to cells $(14,23)$, we investigated how seropositive cat sera bring about the inhibition of syncytium formation by FIV. To address this point, we studied the effect of thoroughly washing off the input virus-serum mixtures after absorption. The representative data presented in Table 2 show that inhibition of syncytium formation is not dependent on the continuous presence of serum in the test cultures and correlates well with inhibition of viral antigen accumulation in the supernatants. In further studies, the addition of high-titer neutralizing sera to cell cultures that had been infected $4 \mathrm{~h}$ earlier did not prevent the formation of the expected numbers of syncytia, although the syncytia pro- 
TABLE 2. Effect of removing virus-serum inocula on neutralization, as determined by syncytium formation and viral antigen production

\begin{tabular}{|c|c|c|c|c|c|c|}
\hline \multirow{4}{*}{$\begin{array}{l}\text { Serum } \\
\text { dilution }\end{array}$} & \multicolumn{6}{|c|}{ Results with serum: } \\
\hline & \multicolumn{3}{|c|}{ M2-IV } & \multicolumn{3}{|c|}{ M2-VIIb } \\
\hline & \multirow{2}{*}{$\begin{array}{l}\text { No. of syncytia } \\
\text { without removal }\end{array}$} & \multicolumn{2}{|c|}{ With removal ${ }^{b}$} & \multirow{2}{*}{$\begin{array}{l}\text { No. of syncytia } \\
\text { without removal }\end{array}$} & \multicolumn{2}{|c|}{ With removal } \\
\hline & & $\begin{array}{l}\text { No. of } \\
\text { syncytia }\end{array}$ & $\begin{array}{l}\text { Optical } \\
\text { density }\end{array}$ & & $\begin{array}{l}\text { No. of } \\
\text { syncytia }\end{array}$ & $\begin{array}{l}\text { Optical } \\
\text { density }\end{array}$ \\
\hline $1: 256$ & 0 & 0 & 0.211 & 0 & 0 & $\mathrm{ND}^{d}$ \\
\hline $1: 512$ & 0 & 0 & 0.203 & 0 & 0 & ND \\
\hline $1: 1,024$ & 0 & 0 & 0.219 & 0 & 0 & 0.216 \\
\hline $1: 2,048$ & 0 & 0 & 0.263 & 0 & 0 & 0.213 \\
\hline $1: 4,096$ & 0 & 0 & 0.271 & 0 & 0 & 0.210 \\
\hline $1: 8,192$ & $4 \pm 2$ & 0 & 0.242 & 0 & $16 \pm 5$ & 0.473 \\
\hline $1: 16,384$ & $18 \pm 4$ & $14 \pm 4$ & 0.846 & 8 & $22 \pm 6$ & 0.477 \\
\hline FIV alone & $61 \pm 8$ & $59 \pm 10$ & 2.708 & & & \\
\hline No FIV & 0 & 0 & 0.227 & & & \\
\hline
\end{tabular}

${ }^{a}$ Mean \pm standard deviation.

${ }^{b}$ Four hours after inoculation, that is, at a time when most FIV has become absorbed to CrFK-MESNA cells but no syncytia have formed (22), the FIV-serum inocula were washed off and replaced with fresh medium.

$c$ At the end of the 6-day incubation period, the cultures were examined by ELISA for FIV p24 antigen content as well as for syncytia. The p24 assay was performed on pooled supernatants of the cultures as described elsewhere (21), with minor modifications.

${ }^{d}$ ND, not determined.

duced were smaller (data not shown). These results show that inhibition of syncytium formation is due to a true neutralization of FIV infectivity prior to its entry into cells and not to down-regulation of syncytium formation or other mechanisms.

This study confirms recent findings (5) showing that cats develop high-titer NA early after FIV infection. NA may contribute to the long incubation period between infection and illness observed in FIV-infected cats as well as to the fact that FIV transmission in utero is a rare event which possibly occurs only during primary infection $(4,15,24,25)$. However, FIV was readily isolated from the peripheral blood mononuclear cells of animals with high levels of NA in their sera, indicating that NA are unable to terminate an established FIV infection. This is in keeping with previous results (5) and with our present understanding of the role of NA in HIV type infection $(11,12)$. It has been suggested that NA mediate the reduction of high-titer viremia which occurs in human plasma soon after infection (1). Nevertheless, FIV could be isolated from plasma regardless of the NA titers (10).

The neutralizing activity found at low titers in few apparently noninfected cats deserves further investigation. Since it was observed in cats who were also negative by Western blot (immunoblot) assay (data not shown), the result does not seem to stem from the low sensitivity of the ELISA used. Since it was detected in field cats but not in SPF cats, explanations to be considered include cross-reactivity of FIV with other cat pathogens (cats singly infected with feline leukemia virus or feline syncytium-forming virus, however, tested negative), the possibility that the neutralization test detects FIV infections not detected by other currently used serological methods $(6,8)$, the possibility that NA persist longer than other antibodies and represent footprints of an eradicated FIV infection, and the possible existence of nonspecific inhibitors.

However, the most important finding of the present study is the large degree of cross-neutralization exhibited by FIV isolates from different geographical areas, indicating that FIV contains one or more highly conserved neutralization epitopes. This information may be useful in the preparation of effective vaccines. HIV, which can be considered the human counterpart of FIV, also contains regions which elicit broadly reactive neutralizing responses $(3,7,11,12)$, though its env gene variability appears to be higher than that of FIV (17). We are currently trying to identify the FIV epitope(s) involved in neutralization.

This work was supported by grants from the Ministero della Sanità-Istituto Superiore di Sanità "Progetto Allestimento Modelli Animali per l'AIDS" and "Progetto FATHA," CNR, Rome, Italy.

We are grateful to Marian C. Horzinek, University of Utrecht; Oswald Jarrett, University of Glasgow; Hans Lutz, University of Zurich; and Niels C. Pedersen, University of California, Davis, for suggestions and reagents.

\section{REFERENCES}

1. Albert, J., H. Gaines, A. Sönnerborg, G. Nyström, P. 0. Pehrson, F. Chiodi, M. von Sydow, L. Moberg, K. Lidman, B. Christensson, B. Åsjö, and E. M. Fenyö. 1987. Isolation of human immunodeficiency virus from plasma during HIV infection. J. Med. Virol. 23:67-73.

2. Bandecchi, P., D. Matteucci, F. Baldinotti, G. Guidi, G., F. Tozzini, and M. Bendinelli. 1992. Prevalence of feline immunodeficiency virus and other retroviral infections in sick cats in Italy. Vet. Immunol. Immunopathol. 31:337-345.

3. Berkower, I., G. E. Smith, C. Giri, and D. Murphy. 1985. Human immunodeficiency virus-1: predominance of a groupspecific neutralizing epitope that persists despite genetic variation. J. Exp. Med. 170:1681-1695.

4. Callanan, J. J., M. J. Hosie, and O. Jarrett. 1991. Transmission of feline immunodeficiency virus from mother to kitten. Vet. Rec. 128:332-333.

5. Fevereiro, M., C. Roneker, A. Laufs, L. Tavares, and F. de Noronha. 1991. Characterization of two monoclonal antibodies against feline immunodeficiency virus gag gene products and their application in an assay to evaluate neutralizing antibody activity. J. Gen. Virol. 72:617-622.

6. Harbour, D. A., P. D. Williams, T. J. Gruffydd-Jones, J. Burbridge, and G. R. Pearson. 1988. Isolation of a T-lymphotropic lentivirus from a persistently leukopenic domestic cat. Vet. Rec. 122:84-86.

7. Ho, D. D., J. C. Kaplan, I. E. Rackauskas, and M. E. Gurney. 1988. Second conserved domain of gp120 is important for HIV infectivity and antibody neutralization. Science 239:1021-1023.

8. Hopper, C. D., A. H. Sparkes, T. J. Gruffydd-Jones, S. M. Crispin, P. Muir, D. A. Harbour, and C. R. Stokes. 1989. Clinical and laboratory findings in cats infected with feline 
immunodeficiency virus. Vet. Rec. 125:341-346.

9. Hosie, M. J., C. Robertson, and O. Jarrett. 1989. Prevalence of feline leukaemia virus and antibodies to feline immunodeficiency virus in cats in the United Kingdom. Vet. Rec. 128:293297.

10. Matteucci, D., F. Baldinotti, P. Mazzetti, M. Pistello, P. Bandecchi, R. Ghilarducci, A. Poli, F. Tozzini, and M. Bendinelli. 1993. Detection of feline immunodeficiency virus in saliva and plasma by cultivation and polymerase chain reaction. J. Clin. Microbiol. 31:494-501.

11. McKeating, J. A. 1992 . Neutralization of human immunodeficiency virus. Rev. Med. Virol. 2:35-42.

12. Nara, P. L., R. R. Garrity, and J. Goudsmit. 1991. Neutralization of HIV-1: a paradox of humoral proportions. FASEB J. 5:2437-2455.

13. O'Connor, T. P., Jr., S. Tanguay, R. Steinman, R. Smith, M. C. Barr, J. K. Yamamoto, N. C. Pedersen, P. R. Andersen, and Q. J. Tonelli. 1989. Development and evaluation of immunoassay for detection of antibodies to the feline T-lymphotropic lentivirus (feline immunodeficiency virus). J. Clin. Microbiol. 27:474-479.

14. Pantaleo, G., G. Poli, L. Butini, C. Fox, A. I. Dayton, and A. S. Fauci. 1991. Dissociation between syncytia formation and HIV spreading. Suppression of syncytia formation does not necessarily reflect inhibition of HIV infection. Eur. J. Immunol. 21:1771-1774.

15. Pedersen, N. C. Feline immunodeficiency virus infection. In J. A. Levy (ed.), The Retroviridae, vol. 2, in press. Plenum Press, New York.

16. Pedersen, N. C., E. W. Ho, M. L. Brown, and J. K. Yamamoto. 1987. Isolation of a T-lymphotropic virus from domestic cats with an immunodeficiency-like syndrome. Science 235:790-793.

17. Phillips, T. R., R. L. Talbott, C. Lamont, S. Muir, K. Lovelace, and J. L. Elder. 1990. Comparison of two host cell range variants of feline immunodeficiency virus. J. Virol. 64:46054613.

18. Rigby, M. A., E. C. Holmes, M. Pistello, A. Mackay, A. J. Leigh
Brown, and J. C. Neil. Evolution of structural proteins of feline immunodeficiency virus: molecular epidemiology and evidence of selection for change. AIDS, in press.

19. Schellekens, H., and M. C. Horzinek (ed.). 1990. Animal models in AIDS. Elsevier Science Publishers, Amsterdam.

20. Siebelink, K. H. J., I.-H. Chu, G. F. Rimmelzwaan, K. Weijer, A. D. M. E. Osterhaus, and M. L. Bosch. 1992. Isolation and partial characterization of infectious molecular clones of feline immunodeficiency virus obtained directly from bone marrow DNA of a naturally infected cat. J. Virol. 66:1091-1097.

21. Siebelink, K. H. J., R. W. Windrich, I. Chu, J. Groen, K. Weijer, F. G. C. M. UytdeHaag, and A. D. M. E. Osterhaus. 1990. An enzyme linked immunosorbent assay (ELISA) for the detection of feline immunodeficiency virus (FIV) antigen in cell culture and FIV specific antibodies in feline serum. Dev. Biol. Stand. 72:189-196.

22. Tozzini, F., D. Matteucci, P. Bandecchi, F. Baldinotti, A. Poli, M. Pistello, K. H. J. Siebelink, L. Ceccherini-Nelli, and M. Bendinelli. 1992. Simple in vitro methods for titrating feline immunodeficiency virus (FIV) and FIV neutralizing antibodies. J. Virol. Methods 37:241-252.

23. Ushijima, H., S. Unten, H. Honma, H. Tsuchie, T. Kitamura, B. E. Weiler, and W. E. G. Mueller. 1991. Differential effect of serum on syncytium formation and virus production in cells chronically infected with HIV in vitro. AIDS 5:1386-1388.

24. Yamamoto, J. K., H. Hansen, E. W. Ho, T. Y. Morishita, T. Okuda, T. R. Sawa, R. M. Nakamura, and N. C. Pedersen. 1989. Epidemiologic and clinical aspects of feline immunodeficiency virus infection in cats from the continental United States and Canada and possible mode of transmission. J. Am. Vet. Med. Assoc. 194:213-220.

25. Yamamoto, J. K., E. Sparger, E. W. Ho, P. R. Andersen, T. P. O'Connor, C. P. Mandell, L. Lowenstine, R. Munn, and N. C. Pedersen. 1988. Pathogenesis of experimentally induced feline immunodeficiency virus infection in cats. Am. J. Vet. Res. 49:1246-1258. 